\title{
EXPERIENCIA PERUANA EN EL DESPLIEGUE DE LA INFRAESTRUCTURA DE LAS COMUNICACIONES MÓVILES
}

\author{
PERUVIAN EXPERIENCE ON THE DEPLOYMENT OF INFRASTRUCTURE \\ FOR MOBILE COMMUNICATIONS
}

\author{
Víctor Cruz Ornetta ${ }^{1}$ y Jorge Ubillus Gonzales ${ }^{2}$
}

\section{RESUMEN}

El principal objetivo de este estudio ha sido resumir las acciones más importantes que fueron realizadas en el tema de los radianes no ionizantes. Estos actos se hicieron en el Perú para lograr el despliegue de la infraestructura de las comunicaciones móviles. Las principales acciones fueron realizadas por el Instituto Nacional de Investigación y Capacitación de Telecomunicaciones (INICTEL), actualmente INICTEL-UNI; el Ministerio de Transportes y Comunicaciones (MTC), especialmente a través de la Dirección de Control y Supervisión de Telecomunicaciones (DGCST-MTC); y la Universidad Nacional Mayor de San Marcos (UNMSM) principalmente por medio de la Facultad de Ingeniería Electrónica y Eléctrica (FIEE-UNMSM). Se incluye la evaluación de los efectos en la salud y la regulación, la cual estuvo basada en varios documentos internacionales importantes, especialmente aquellos que fueron producidos dentro del marco del Proyecto Internacional Campos Electromagnéticos de la Organización Mundial de la Salud (OMS) realizada por el INICTEL-UNI y la FIEEUNMSM. Se considera, además, los resultados de las más importantes evaluaciones peruanas, que se hacen a los principales servicios y sistemas de telecomunicaciones (radiofrecuencias) y se realizan desde el 2000 al 2015. Asimismo, se resaltan las acciones realizadas para divulgar la información y evitar la alarma social. Las mediciones y evaluaciones han sido ejecutadas por INICTEL-UNI y el MTC, a nivel nacional, mediante muestras representativas que incluyeron más de 3000 sitios de telecomunicaciones. Estas fueron de banda ancha, gracias al uso de analizadores de campos electromagnéticos, y de banda angosta, con analizadores de espectros y analizadores de radiación electromagnética selectivos. La diseminación de información y la prevención de la alarma social ha sido conducida por el INICTEL-UNI, el MTC y la FIEE-UNMSM.

Palabras clave: Campos electromagnéticos, radiaciones no ionizantes, radiofrecuencias, telecomunicaciones, RF, telefonía móvil, estaciones bases.

\begin{abstract}
The main objective of this study was to summarize the most important actions performed on the non-ionizing radiations issue carried out in Peru, in order to deploy infrastructure for mobile communications. The main actions were performed by the National Institute for Research and Training in Telecommunications (INICTEL), currently INICTEL-UNI, the Ministry of Transports and Communications (MTC), especially the Direction of Control and Supervision of Telecommunications (DGCST-MTC) and the National University of San Marcos (UNMSM), mainly by means of the Faculty of Electronics and Electrical Engineering (FIEE-UNMSM). It included the assessment of health effects and regulation, which was based on several important international documents, specially those which were issued within the frame of the International Electromagnetic Field Project of the World Health Organization (WHO), carried out by INCTEL-UNI and FIEE-UNMSM, the results of the main peruvian assessments on telecommunications services (radiofrequencies) and systems carried out from 2000 to 2015, and actions carried out to spread information and avoid social alarm. The measurements and evaluations were mainly performed by INICTEL-UNI and MTC on a nationwide basis by using representative samples of the sources, which included more than 3000 telecommunications sites. The measurements were broadband, using electromagnetic field analyzers, and narrow band, using selective spectrum analyzers and selective electromagnetic fields analyzers. The dissemination of information and prevention of social alarm has been conducted by INICTEL-UNI, MTC and FIEE-UNMSM.
\end{abstract}

Keywords: Electromagnetic fields, non-ionizing radiations, radiofrequencies, telecommunications, RF, mobile telephony, base stations.

1 Universidad Ricardo Palma, Av. Benavides 5440, Lima, Perú. Universidad Nacional Mayor de San Marcos, Av. Venezuela s/n, Lima, Perú. <victor.cruzo@urp.pe>

2 Universidad Ricardo Palma, Av. Benavides 5440, Lima, Perú. <jorge.ubillusg@urp.pe> 


\section{INTRODUCTION}

Latin American telecommunication networks have had a very fast growth in the last years, but the mobile communications services are the ones that have performed the biggest growth. According to the International Telecommunication Union (ITU), there will be 7000 millions of mobile communications users at the end of 2014 with an average penetration in the American continent of about 108 \% (ITU-D, 2014) and the Peruvian Supervisory Organism for Private Investment in Telecommunications (OSIPTEL), in March 2015, stated that the mobile teledensity in Peru was about $112 \%$ with approximately 32- million users (OSIPTEL, 2015), surpassing largely to fixed telephony subscribers.

Parallel to this very vigorous expansion of the Americas' and Peruvian telecommunication networks, some population sectors have developed a serious concern on possible health effects from nonionizing radiation of telecommunications.

The objective of this study is to give an overview of the Peruvian experience on the deploying of infrastructure for mobile communications presenting the main actions performed such as the review on health effects which is based on the studies carried out primarily within the frame of the WHO International Electromagnetic Fields Project (WHO, 2015), the characterization of the exposure nationwide, the Peruvian regulation and actions to disseminate information and prevent social alarm.

\section{MATERIAL AND METHODS}

\section{Review on Health Effects}

The evaluation of health effects, which has been done in Peru, is based on the most important international and national reviews and was published in 2008 (Cruz, 2009). The results of a new preliminary review were published this year (Cruz, 2015).

In order to evaluate possible health effects from electromagnetic fields (EMF) due to telecommunication networks in Phase I, they were done two activities:

On one hand, a monographic research of the main documents about health effects and a monographic research on regulation about exposure limits were made. On the other hand, a review of publications from international organizations such as the International Agency for Research on Cancer (IARC, 2013), the Institute of Electrical and Electronic Engineers (IEEE, 2006), the International Commission on Non-Ionizing Radiation Protection (ICNIRP,1998; ICNIRP, 2009) and the World Health Organization (WHO, 2014; WHO, 2006; WHO; 2007) was carried out. It was also conducted a review of national documents from Australian Radiation Protection and Nuclear Safety Agency (ARPANSA, 2014), the French Agency of Environmental and Occupational Health Safety (AFSSET, 2009), French Agency for Food, Environmental and Occupational Health and Safety (ANSES, 2013), Direction General of Health of France (Zmirou, 2001), European Commission (SCENIHR,2009), Health Council of the Netherlands (HCN; 2011; HCN, 2013; HCN, 2014), Independent Expert Group on Mobile Phones (IEGMP, 2000), Health Protection Agency (AGNIR,2012) of the United Kingdom and the Royal Society of Canada (RSC,1999).

\section{Legislation on Radiofrequency Fields}

There were revised the web sites of the Peruvian Ministry of Environment, the Peruvian Ministry of Transports and Communications and the website Antenas y Salud (CONAM,2005; MTC,2003, Peruvian Congress, 2007; Peruvian Congress, 2014; MTC, 2015; MTC,2004; MTC, 2004; MTC, 2004; MTC, 2005; MTC, 2005; MTC, 2005). 


\section{Actions to disseminate information and prevent social alarm}

With regard to the dissemination of information and the prevention of social alarm there is no official information, so we rely on information provided by people engaged in non-ionizing work and research from MTC, INICTEL-UNI, FIEE- UNMSM (Cruz, 2002; Cruz,2005; Cruz, 2010; Cruz et al., 2015; DGCST-MTC,2015; Cruz; 2004; Cruz,2006a; Cruz, 2006b; WHO, 2002; WHO, 2002; WHO, 2006a, WHO, 2006b, INICTEL-UNI, 2015; CITEL,2006, INICTEL-UNI; 2009; UNMSM, 2011; UNMSM,2014).

\section{RESULTS}

\section{Identification of problems and objectives}

In Figure 1 and Figure 2, the problem the problem and objective trees of the analysis carried out in Peru are shown.

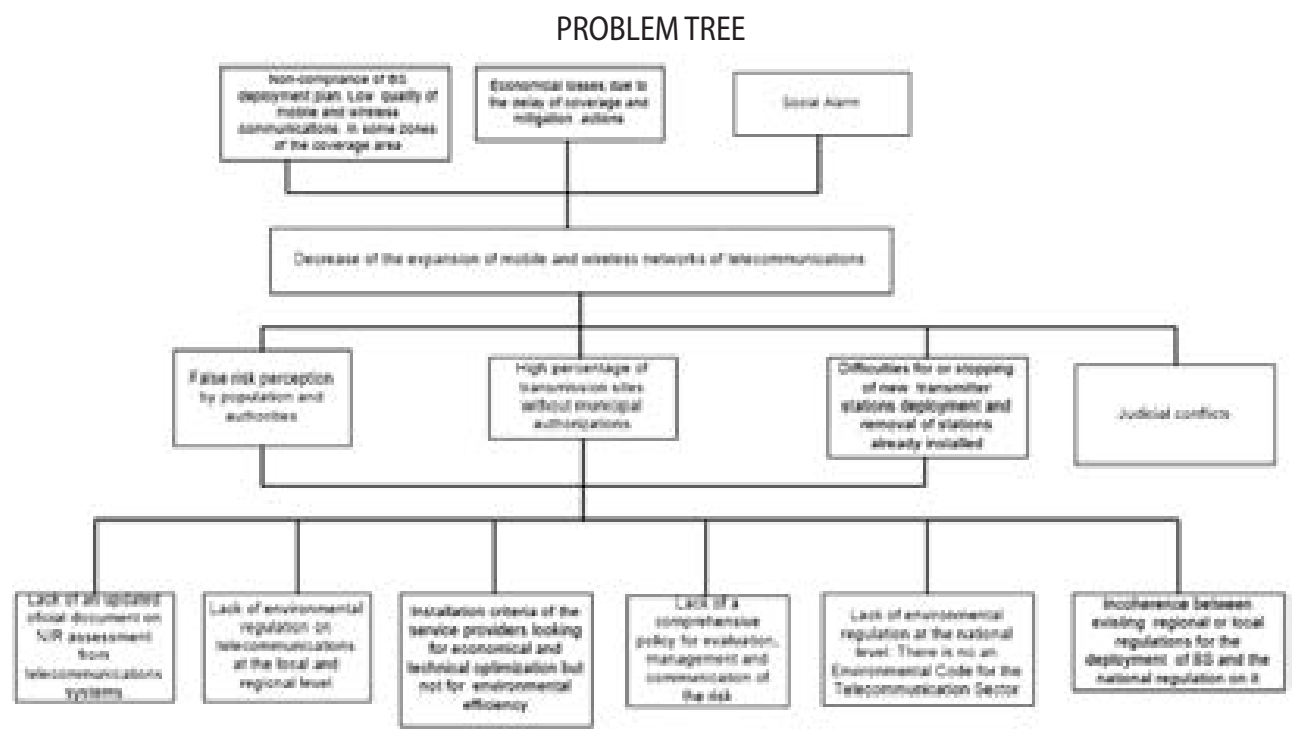

Figure 1: Problem tree for deployment of mobile and wireless telecommunication networks.

\section{Identification of health effects}

The studies on health effects related to the exposure to electromagnetic fields started in the fifties. Currently, the database of the EMF-Portal has approximately 21000 electromagnetic fields studies and the IEEE ICES for radiofrequency includes approximately 2000 studies on mobile telephony and Wi-Fi (see Table 1).

The evaluation of health effects, which has been done in Peru, is based on the most important international and national reviews, and was published in 2009 (Cruz, 2009). The results of a new preliminary review were published this year (Cruz, 2015).

\section{Accute health effects}

Various issues in everyday life tend to increase the heat load on the human body, such as high ambient temperatures, solar radiation, and basal and exercise metabolism. Energy production can reach levels 


\section{OBJECTIVE TREE}

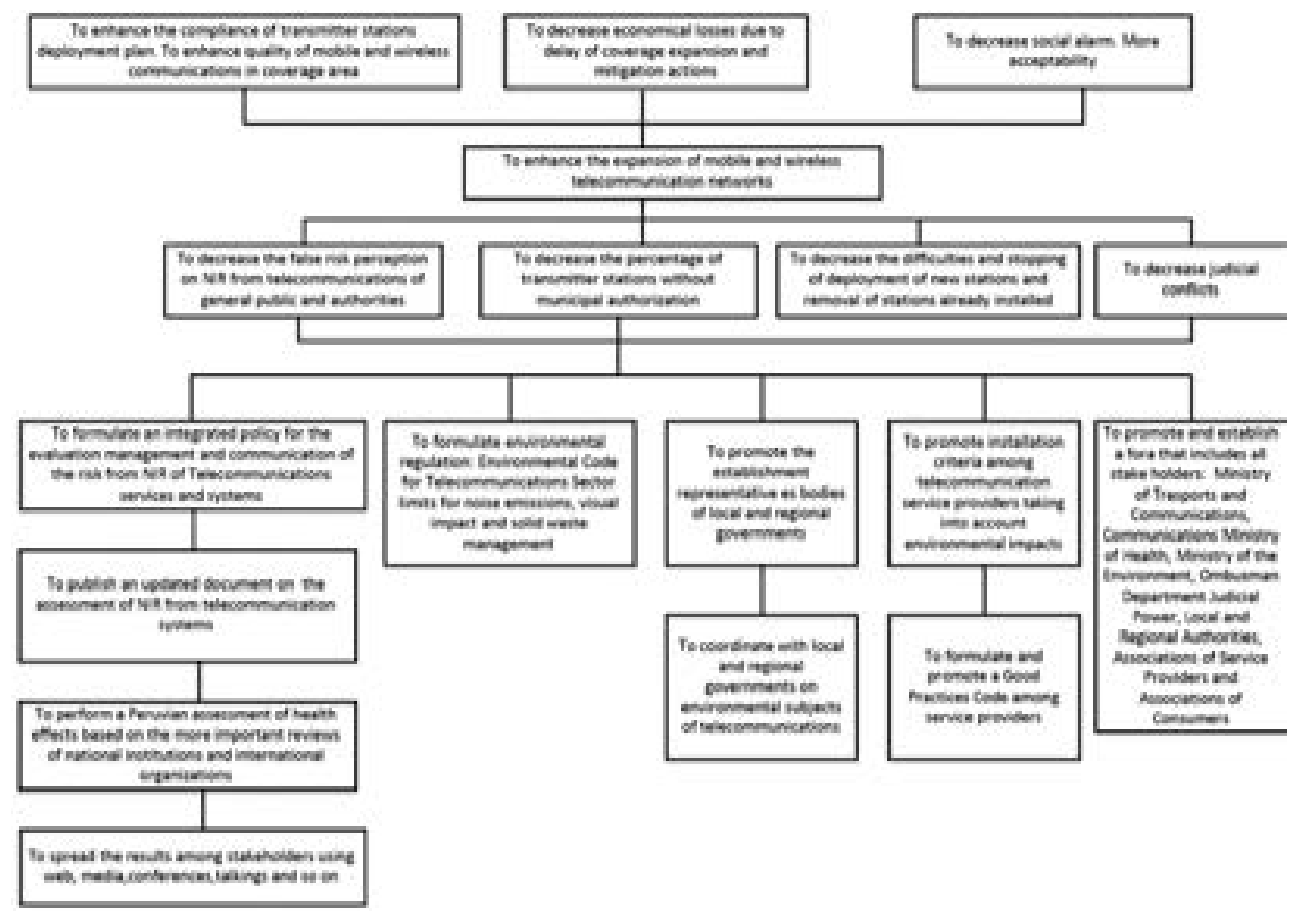

Figure 2: Objective tree for deployment of mobile and wireless telecommunication networks

of 3-6 W/kg in healthy people, but, in most individuals, the thermoregulatory system can manage these rates for extended periods of time.

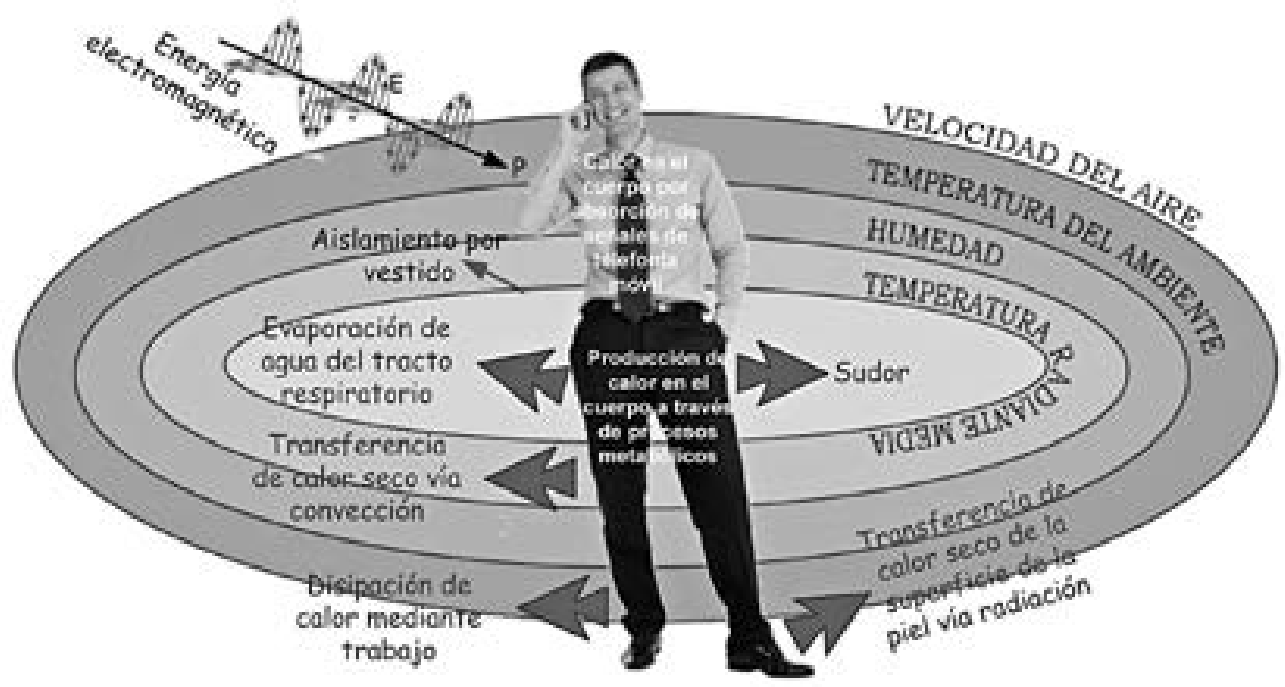

Figure 3: Thermoregulatory processes. 
Limited experimental evidence and theoretical calculations suggest that the exposure to radiofrequency fields of resting humans in moderate environmental conditions at whole body SARs of the order of $1-4 \mathrm{~W} / \mathrm{kg}$ for 30 minutes results in a body temperature increase of less than $1{ }^{\circ} \mathrm{C}$. In addition, a review of the animal data indicates a threshold for behavioural responses in the same $1-4 \mathrm{~W} / \mathrm{kg}$ range. Temperature increase of human body is related, not exclusively to the power dissipated in the local tissue mass, but also by how the absorption is distributed in the surrounding volume by the thermal characteristics of the tissue and its unexposed neighboring tissues. Finally, by the heat exchange with the external environment. (ICNIRP, 2009) (see figure 3).

TABLE 1: DATABASE IEEE STUDIES ON ELECTROMAGNETIC FIELDS FROM MOBILE AND WI-FI SYSTEMS (UPDATED TILL SEPTEMBER 2015).

\begin{tabular}{|l|c|c|c|}
\hline \multicolumn{1}{|c|}{ Study Type/Subtype } & Ongoing & $\begin{array}{c}\text { Reported but } \\
\text { not published }\end{array}$ & Published \\
\hline Engineering \& Physics & 25 & 13 & 382 \\
\hline Epidemiology & 26 & 6 & 307 \\
\hline Human / Provocation & 26 & 17 & 310 \\
\hline In Vitro & 31 & 27 & 293 \\
\hline In Vivo & 20 & 16 & 370 \\
\hline Literature Review, Letter, Book Chapt., Report & 1 & 1 & 14 \\
\hline Plant Studies & 1 & 3 & 9 \\
\hline Social Sciences & 7 & 1 & 86 \\
\hline Total & 137 & 84 & 1771 \\
\hline Grand Total & \multicolumn{2}{|l}{} \\
\hline
\end{tabular}

Exposure to higher electromagnetic field levels that produce SAR values bigger than $4 \mathrm{~W} / \mathrm{kg}$ could be outside thermoregulatory body capacity and produce harmful effects.

In summary, the only established heath effect in humans derived from exposure to radiofrequency fields $(\mathrm{RF})$ are related to thermal effects that could range from behavioural effects to cell death, but, in the case of RF, the increase of temperature is well below $1^{\circ} \mathrm{C}$.

There are other health effects that are being researched such as brain tumour, leukemia or other cancers, cataracts, effects on blood brain barrier, brain activity, cognitive function and male fertility but up to date there is no convincing evidence for any of this possible effects to get the status of established effect (Cruz, 2009; Cruz, 2015; IARC, 2013; IEEE, 2006; ICNIRP,1998; ICNIRP, 2009, WHO, 2014; WHO, 2006; WHO; 2007; ARPANSA, 2014; AFSSET, 2009; ANSES, 2013; Zmirou, 2001; SCENIHR,2009; HCN; 2011; HCN, 2013; HCN, 2014; IEGMP, 2000; AGNIR,2012; RSC,1999).

\section{Regulation}

Based on established biological and health effects found through worldwide research, international exposure limits such as the Guidelines of the International Commission for Non-Ionizing Protection (ICNIRP) [8] were set up. These are the most accepted guidelines for non-ionizing radiation. They are endorsed by the World Health Organization (WHO), the International Union for Telecommunications (ITU), the International Labor Office and more than 30 countries all over the world, including administrations of health, telecommunications, environment and others.

ICNIRP guidelines include the basic restrictions, which are exposure restrictions to electromagnetic fields based on established health effects given in terms of the specific absorption rate (SAR) and power density for radiofrequency. ICNIRP states that "protection against adverse health effects 
requires that these restrictions are not exceeded". ICNIRP guidelines also include the reference levels, which are obtained from the basic restrictions by using computational models and measurement methods and intend to ease the assessment of human exposure to electromagnetic fields by using more practical units to evaluate compliance.

\section{Peruvian Regulation}

Peruvian regulation on non-ionizing radiations from electromagnetic fields has been developed from 2003 and the main ones are the following:

The Environmental Quality Standards for Non Ionizing Radiation (ECAs- RNI) [0 Hz-300 GHz] D.S 010-2005-PCM, was set up by the Peruvian National Council for Environment (CONAM) (currently the Peruvian Ministry of Environment) and endorses ICNIRP guidelines for general public exposure (MINAM, 2005).

The Maximum Permissible Limits for Telecommunication Activities (LMP-RNI for telecommunications) [9 kHz- $300 \mathrm{GHz}$ ] D.S. 038-2003-MTC was issued by the Ministry of Transports and Communications of Peru and endorses ICNIRP guidelines for general public and occupational exposure in the frequency range of telecommunication systems (MTC,2003).

In 2007, it was issued the Law for the Strengthening of Telecommunication Infrastructure Growth which main objective is to make easier the implementation of infrastructure for mobile communications including base stations. This law has undergone several modifications but finally its regulation has been issued in 2015 (Peruvian Congress, 2007; Peruvian Congress, 2014; MTC, 2015).

Besides there are complimentary technical standards (MTC, 2015; MTC, 2004a; MTC, 2004b; MTC, 2004c; MTC, 2005a; MTC, 2005b; MTC, 2005c), which are summarized in Table 2, that is enough to give the framework to have a very reliable verification of compliance of peruvian maximum permissible limits on non-ionizing radiations from telecommunications including procedures for supervision and control, guidelines for theoretical studies, protocols for measurements, establishment of the registry for persons authorized to carried out studies and measurements, and certification of equipment.

TABLE 2: COMPLIMENTARY STANDARDS FOR NON-IONIZING RADIATIONS

\begin{tabular}{|c|c|c|}
\hline Complimentary standard & Approval Instrument & Date of Publication \\
\hline $\begin{array}{l}\text { Procedures for Supervision and Control of Maximum } \\
\text { Permissible Limits of Non-Ionizing Radiations }\end{array}$ & Ministerial Resolution N $610-2004-M T C / 03$ & August $16^{\text {th }}, 2004$ \\
\hline $\begin{array}{l}\text { Guidelines for Conducting Theoretical Studies on } \\
\text { Non-lonizing Radiatons }\end{array}$ & Ministerial Resolution N 612-2004-MTC/03 & August $17^{\text {th }}, 2004$ \\
\hline $\begin{array}{l}\text { Technical Norm on Protocols for Measurement of } \\
\text { Non-ionizing Radiatons }\end{array}$ & Ministerial Resolution N 613-2004-MTC/03 & August $17^{\text {th }}, 2004$ \\
\hline $\begin{array}{l}\text { Technical Norm on Radio Restrictions in Areas of } \\
\text { Public Use }\end{array}$ & Ministerial Resolution N $120-2005-M T C / 03$ & February $23^{\text {rd }}, 2005$ \\
\hline $\begin{array}{l}\text { Directive for Implementation of the Registry for } \\
\text { Persons Authorized to Conduct Theoretical Studies } \\
\text { and Measurements of Non-Ionizing Radiations }\end{array}$ & $\begin{array}{l}\text { Ministerial Resolution N }{ }^{\circ} \text { 534-2005-MTC/03 modified } \\
\text { by Ministerial Resolution N 379-2006-MTC/03 }\end{array}$ & $\begin{array}{l}\text { August 5th, } 2005 \\
\text { May 12th, } 2006\end{array}$ \\
\hline $\begin{array}{l}\text { Directive for the Certification of Non-Ionizing Radia- } \\
\text { tion Measurement Equipment }\end{array}$ & Ministerial Resolution No 965-2005-MTC/03 & $\begin{array}{l}\text { December 22nd, } \\
2005\end{array}$ \\
\hline $\begin{array}{l}\text { Law for the strengthening of the telecommunication } \\
\text { infrastructure growth }\end{array}$ & Law N 29022-modified by Law 30228 & $\begin{array}{l}\text { May 18th, } 2007 \\
\text { July 12th, } 2014 \\
\end{array}$ \\
\hline $\begin{array}{l}\text { Regulation of the Law } N^{\circ} 29022 \text { - Law for } \\
\text { the strengthening of the telecommunication } \\
\text { infrastructure growth }\end{array}$ & Supreme Decree № 003-2015-MTC & April18th, 2015 \\
\hline
\end{tabular}




\section{Evaluation of non-ionizing radiation from telecommunication systems}

National diagnosis on non-ionizing radiations from telecommunication services 2001-2002

In 2001-2002 there were carried out measurements of electric field strength of the main services in the frequency band $50 \mathrm{MHz}$ to $2 \mathrm{GHz}$, including FM Radio, Television, Trunking, Mobile Telephony and Personal Communication Service (PCS) in Lima and other 6 cities: Cuzco, Huancayo, Ica, Iquitos, Pucallpa y Trujillo, with a total of 174 measurement locations (Cruz, 2002) the results are shown in figure 4.

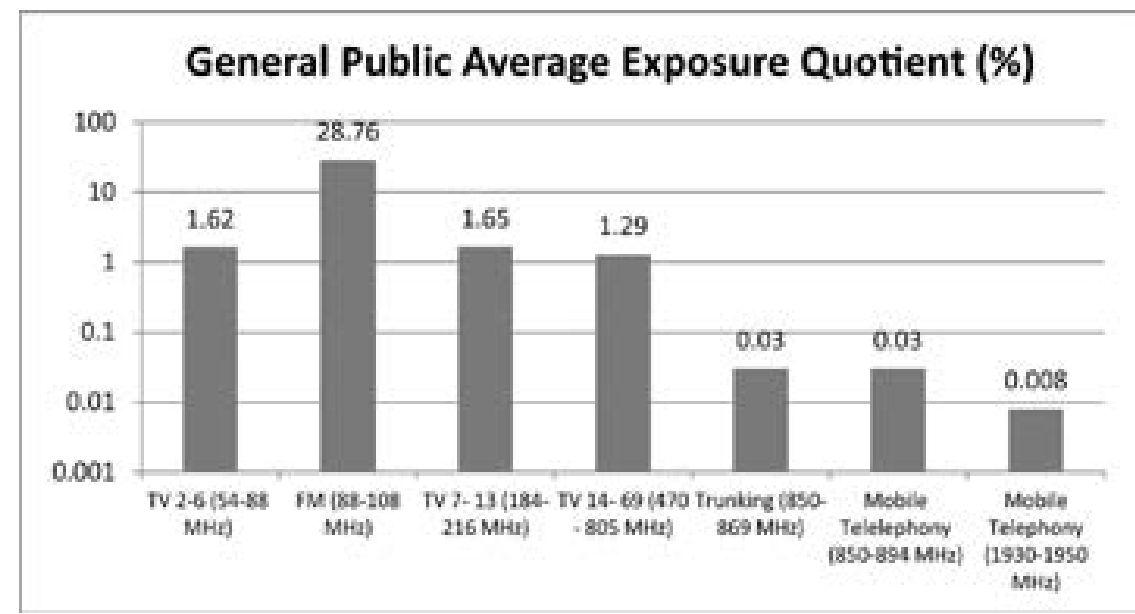

Figure 4: General public average exposure quotient for telecommunication services with regard to ICNIRP limits

Evaluation of Mobile Base Stations 2005:

In 2005, it was carried out an evaluation of 40 base stations in Lima (Cruz, 2005a) whose results are presented in figure 5 .

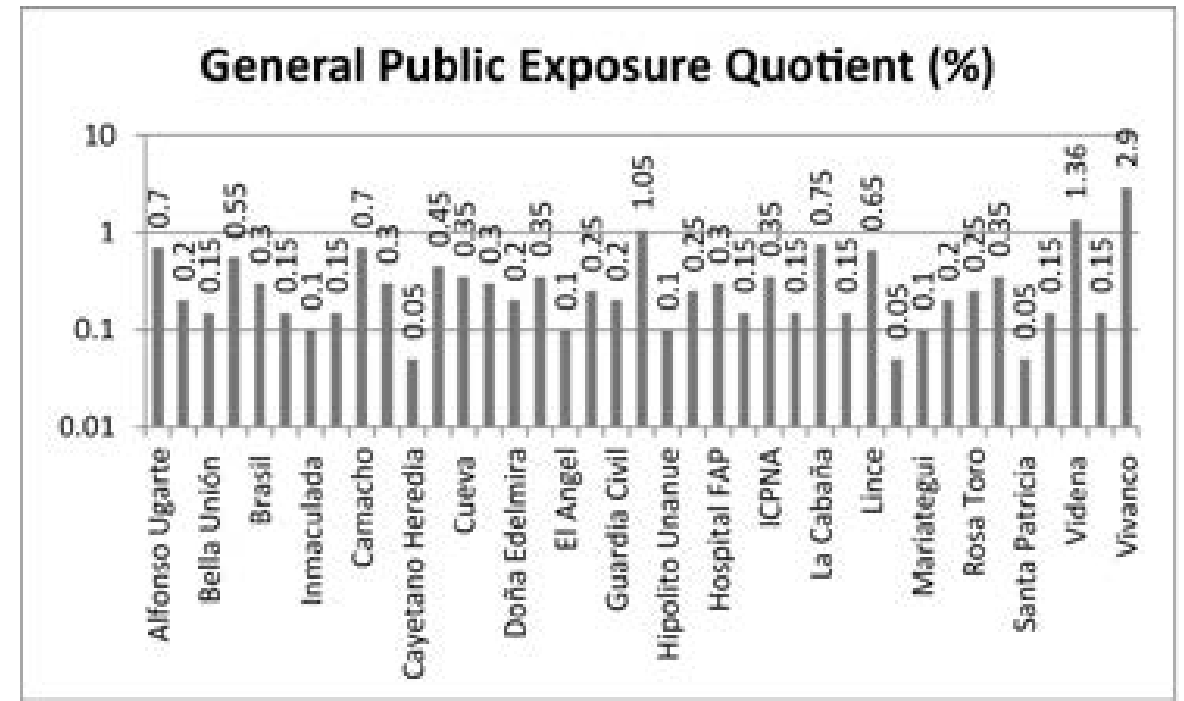

Figure 5: General public exposure quotient for mobile base stations in Lima with regard to ICNIRP limits. 
Evaluation of Mobile Phones in 2005 and 2010:

In 2005, it was carried out the first risk assessment of electromagnetic fields (EMF) from mobile telephony in Peru (Cruz,2005b), which included the evaluation of SAR values of 205 mobile phones certified by the Peruvian Ministry of Transports and Communications (MTC) among 367 phones that were registered in MTC database. The top 10 SAR values had an exposure quotient in the range $73 \%-79 \%$ with regard to general public ICNIRP limits.

Then, in 2010, it was published the second EMF evaluation of mobile phones certified in Peru (Cruz et al., 2010), that pointed out the top 10 SAR values in the range of 1.52 to $1.6 \mathrm{Wkg}^{-1}$ with exposure quotient in a range from $76 \%$ to $80 \%$ with regard to general public ICNIRP limits .

Finally, in 2014, it was carried out the last EMF evaluation of mobile phones certified in Peru (Cruz et al., 2015) that pointed out the top 10 SAR values in the range of 1.51 to $1.73 \mathrm{Wkg}^{-1}$ with exposure quotient in the range $75.5 \%$ to $86.5 \%$ with regard to general public ICNIRP limits.

TABLE 3: THE TOP TEN SAR VALUES IN 2015.

\begin{tabular}{|c|c|c|c|c|}
\hline \multirow{2}{*}{ Code } & \multirow{2}{*}{ Brand } & Model & \multicolumn{2}{|c|}{ Head } \\
\cline { 4 - 5 } & & & Wkg- $10 \mathrm{~g}$ & $\begin{array}{c}\text { General Public } \\
\text { Quotient ICNIRP (\%) }\end{array}$ \\
\hline TRFM14145 & BLACKBERRY & $7130 \mathrm{~g}$ & 1.73 & $86.5 \%$ \\
\hline TRFM26701 & SONY & ST25a & 1.62 & $81 \%$ \\
\hline TRFM27533 & SONY & ST25i & 1.62 & $81 \%$ \\
\hline TRFM27601 & BLACKBERRY & CURVE 9220 & 1.61 & $80.5 \%$ \\
\hline TRFM27451 & BLACKBERRY & REX41GW (9220) & 1.61 & $80.5 \%$ \\
\hline TRFM16004 & SAMSUNG & SGH C516 & 1.6 & $80 \%$ \\
\hline TRFM22570 & SONY ERICSSON & SATI0 & 1.58 & $79 \%$ \\
\hline TRFM23916 & MOTOROLA & EX119 & 1.56 & $78 \%$ \\
\hline TRFM31321 & NOKIA & RM 977 & 1.51 & $75.5 \%$ \\
\hline TRFM25049 & NOKIA & NOKIA 300 & 1.51 & $75.5 \%$ \\
\hline
\end{tabular}

Evaluation of non-ionizing radiation from telecommunication services 2013-2014:

The last three years, the Ministry of Transports and Communications (MTC) has conducted a very aggressive nationwide measurement program of non-ionizing radiations from telecommunication services (Antenas y Salud, 2015). More than 3000 measurements had been carried out by MTC from 2012-2015. From 2013 to 2014, approximately 1700 places in 20 Peruvian regions were evaluated (see figure 6).

\section{Actions to Disseminate Information and Prevent Social Alarm}

\section{Publications}

- The main publications on this subject have been focuses on mobile telephony, but, also, there were done some translation of important documents from WHO, as following:

- The Mobile Telephony and your Health (in Spanish) (Cruz, 2004).

- The Mobile Telephony Networks and Human Health (in Spanish) (Cruz, 2006).

- Environmental Management of Mobile Telphony (in Spanish) (Cruz, 2006).

- Health Risk to Non-Ionizing Radiation by the Telecommunications Networks in Peru (in Spanish) (Cruz, 2009). 


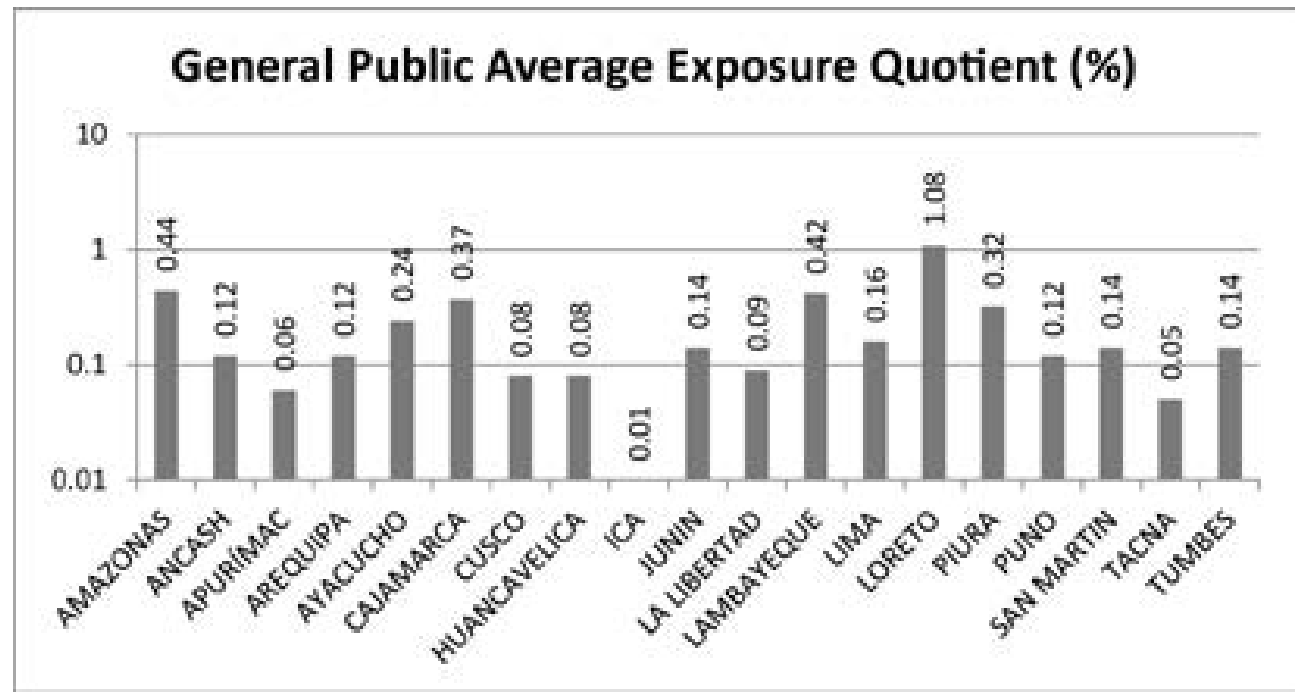

Figure 6: General public average exposure quotient for telecommunication services in peruvian regions with regard to ICNIRP limits.

- $\quad$ The Mobile and Wireless Comunications and Health (in Spanish) (Cruz, 2015).

\section{Translations}

- Establishing a Dialogue on Risks from Electromagnetic Fields [Estableciendo un diálogo sobre los riesgos de los campos electromagnéticos] (WHO, 2002), translated by Víctor Cruz and Úrsula Cangahuala, 2006.

- Framework for Developing Health-Based EMF Standards [Marco para el desarrollo de estándares de CEM basados en la salud] (WHO, 2006a), translated by Víctor Cruz, 2007.

- Model Legislation for Electromagnetic Fields Protection [Legislación modelo para la protección contra los campos electromagnéticos] (WHO, 2006b), translated by Víctor Cruz, 2007.

Symposiums, workshops, forums and conferences

- Regional Meetin-Latin America and Caribe- International WHO Symposium on: "EMF Health Effects, Standards Harmonization and Mitigation Measures", Lima (Peru), 7-9 March 2001, organized by INICTEL (INICTEL-UNI, 2015).

- International CITEL Workshop "Technical and Regulatory Aspects of the Effects of NonIonizing Electromagnetic Emissions”, Lima, Peru, 19 June 2006, organized by CITEL, MTC and INICTEL (CITEL, 2006).

- International Forum -Telecommunication Antennas and Human Health "WHO: Myths and Truths on Non-Ionizing Radiations", Lima, Peru, 2-3 December 2009, organized by INICTELUNI (INICTEL-UNI, 2009).

- International Forum -Telecommunication Antennas Development, Inclusion and Human Health "WHO: Results of the Research on Non-Ionizing Radiations-2011", Lima, Peru, 2-3 December 2011, organized by UNMSM and MTC (UNMSM, 2011).

- International Forum -Telecommunication Antennas Development, Inclusion and Human Health "WHO: Results of the Research on Non-Ionizing Radiations-2014", Lima, Peru, 10-11 July 2014, organized by UNMSM and MTC (UNMSM, 2014). 


\section{Information on Web}

\section{Currently, we have a very active website on the subject of mobile communication: Antenas y Salud (DGCST-MTC, 2015).}

\section{CONCLUSIONS}

- In general, Peru has conducted many actions in order to facilitate the deployment of mobile communications.

- These actions have consisted of the identification of health effects, the stablishment of regulation on NIR, the evaluation of non-ionizing radiation from telecommunication systems and the dissemination of information and prevention of social alarm.

- The results are very extensive, including the issuing of the environmental standard for NIR and the maximum permissible limits to NIR from telecommunications activities, but we still face some concern about antennas deployment.

- The ICNIRP limits have been endorsed by the Environmental Administration as the Peruvian Quality Standards for Non -Ionizing Radiations and for the Telecommunications Administration as the Maximum Permissible Limit for Non -Ionizing Radiations from Telecommunication Services.

- In general, in Peru, the concern on non-ionizing radiation from telecommunication networks, specially from mobile communications networks, is a problem of risk perception. In order to manage the social alarm, it is recommended the implementation of very good communication programs.

- It is necessary to establish a permanent coordination between the national authorities for telecommunications and local governments in order to prevent people from invading the zones near the sites of radio stations for telecommunications.

- The general assessment on EMF from telecommunications demonstrated that most of the telecommunication stations comply with general public ICNIRP limits.

- The average level of electromagnetic fields from FM radio are the biggest one (nearly 29\%) of general public ICNIRP limits, and the values from PCS are the lowest ones (approximately $0.01 \%$ ).

- None of the measurements exceeded the maximum exposure limits for general public areas.

- From the measurements performed, it was possible to have a good picture of the electric field variation vs.distance. The level at some $\mathrm{cm}$. of the antenna is the highest and could be several times above the general public limits and decay quickly in such a way that at $1 \mathrm{~m}$. of the antenna they are below $5 \%$ and at $20 \mathrm{~m}$. it can be below $1 \%$, then it can raise a little until a maximum that can be below $1,5 \%$ in the range between 50 to $150 \mathrm{~m}$, finally, the level fall completely.

\section{REFERENCES}

AFFSET. (2009). Update on Radiofrequencies Expertise (2009). Paris: AFSSET. Available at http:// www.radiofrequences.gouv.fr/IMG/pdf/Afsset_rapport_RF_octobre_2009.pdf (in french).

AGNIR. (2012) Health Effects from Radiofrequency Electromagnetic Fields. Chilton: HPA. Available at https:/www.gov.uk/government/uploads/system/uploads/attachment_data/file/333080/ RCE-20_Health_Effects_RF_Electromagnetic_fields.pdf 
ANSES. (2013). Radiofrequency and Health (2013). Paris: ANSES. Available at https://www.anses.fr/ fr/documents/AP2011sa0150Ra.pdf

ARPANSA. (2014). Review of Radiofrequency Health Effects Research - Scientific Literature 2000 2012. Yallambie: ARPANSA. Available at http://www.arpansa.gov.au/pubs/technicalreports/ tr164.pdf

Cruz, V. (2002). National Diagnosis of Non- Ionizing Radiation from Telecommunication Services (in Spanish). (Master degree thesis), Universidad Ricardo Palma, Lima, Perú.

Cruz, V. (2005). Measurement and Evaluation of Non Ionizing Radiation from 40 Mobile Services Base Stations in Lima City. Lima: INICTEL.

Cruz, V. (2009) Health Risk to Non-Ionizing Radiation by the Telecommunications Networks in Peru (in Spanish). Rev Peru Med Exp Salud Publica, 26(1), 94-103.

Cruz, V. (2015) The Mobile Communications and Health (in Spanish). Lima: UNMSM.

Health Council of the Netherlands. (2011). GSM. Influence of Radiofrequency Telecommunication Signals on Children's Brains. Publication No 2011/20E. The Hague: Health Council of the Netherlands.

Health Council of the Netherlands. (2013). Mobile Phones and Cancer- Part 1: Epidemiology of Tumours in the Head. Publication $N^{\circ}$ 2013/11. The Hague: Health Council of the Netherlands. Available at http://www.gezondheidsraad.nl/sites/default/files/201311_Mobile_Phones_Cancer_Part1.pdf

Health Council of the Netherlands. (2014). Mobile phones and Cancer- Part 2. Animal studies on Carcinogenesis. Publication $N^{\circ}$ 2014/22. The Hague: Health Council of the Netherlands. Available at: http://www.gezondheidsraad.nl/sites/default/files/mobile_phones_and_cancer_ part_2_animal_studies_on_carcinogenesis.pdf

IARC. (2013). IARC Monographs-Non-Ionizing Radiation. Part 2: Radiofrequency Electromagnetic Fields. Lyon: IARC. Available at http://monographs.iarc.fr/ENG/Monographs/vol102/ mono102.pdf

ICNIRP. (1998). Guidelines for Limiting Exposure to Time-Varying Electric, Magnetic, and Electromagnetic Fields (Up to $300 \mathrm{GHz}$ ). Health Phys, 74(4), 494-522.

ICNIRP. (2009) Exposure to High Frequency Electromagnetic Fields, Biological Effects and Health Consequences (100 kHz-300 GHz) - Review of the Scientific Evidence and Health Consequences. Munich: ICNIRP.

IEEE. (2006). IEEE Standard for Safety Levels with Respect to Human Exposure Levels to Radio Frequency Electromagnetic Fields, $3 \mathrm{kHz}$ to $300 \mathrm{GHz}$, IEEE Standard C95.1. New York: IEEE.

IEGMP. (2000). Mobile Phones and Health. Report of an Independent Group on Mobile Phones (2000). Chilton: NRPB. Available at http://webarchive.nationalarchives.gov.uk/20101011032547/http:/ www.iegmp.org.uk/

ITU-D. (2014). The World in 2014- ICT Facts and Figures. Geneva: ITU. Available at https://www.itu.int/en/ITU-D/Statistics/Documents/facts/ICTFactsFigures2014-e.pdf

Ministry of the Environment. (2005). Environmental Quality Standards for Non Ionizing Radiation (ECAs- RNI) [0-300 GHz], Supreme Decree No 010-2005-PCM (in Spanish). Lima: CONAM. Available at http://www.minam.gob.pe/wp-content/uploads/2013/10/compendio_05_-_calidad_ambiental_2.pdf

Ministry of Transports and Communications. (2003). The Maximum Permissible Limits (LMP) for Non-ionizing Radiations from Telecommunications, Supreme Decree $N^{\circ}$ 038-2003-MTC (in Spanish). Lima: El Peruano.

Ministry of Transports and Communications. (2004). Guidelines for Conducting Theoretical Studies on Non-Ionizing Radiatons- Ministerial Resolution N ${ }^{\circ}$ 612-2004-MTC/03. Available at http://antenasysalud.pe/wp-content/uploads/2015/04/RM-612-200418-08-2004.pdf 
Ministry of Transports and Communications. (2004). Procedures for Supervision and Control of Maximum Permissible Limits of Non-Ionizing Radiations-Ministerial Resolution $N^{\circ}$ 610-2004MTC/03. Available at http://antenasysalud.pe/wp-content/uploads/2015/04/RadiacionesRM-610-200417-08-2005.pdf

Ministry of Transports and Communications. (2004). Technical Norm on Protocols for Measurement of Non-ionizing Radiatons- Ministerial Resolution $N^{\circ}$ 613-2004-MTC/03. Available at http://antenasysalud.pe/wp-content/uploads/2015/04/RM-613-200419-08-2005.pdf

Ministry of Transports and Communications. (2005). Directive for Implementation of the Registry for Persons Authorized to Conduct Theoretical Studies and Measurements of Non-Ionizing RadiationsMinisterial Resolution $N^{\circ}$ 534-2005-MTC/03. Available at http://antenasysalud.pe/wp-content/ uploads/2015/04/Registro-RM-534-200513-08-2005.pdf

Ministry of Transports and Communications. (2005). Directive for the Certification of Non-Ionizing Radiation Measurement Equipment- Ministerial Resolution No 965-2005-MTC/03. Available at: http://antenasysalud.pe/wp-content/uploads/2015/04/Directiva-Equip-noionizantes.pdf

Ministry of Transports and Communications. (2005). Technical Norm on Radio Restrictions in Areas of Public Use-Ministerial Resolution $N^{\circ}$ 120-2005-MTC/03. Available at http://antenasysalud.pe/ wp-content/uploads/2015/04/RM-120-2005-Restricciones-radioelectricas.pdf

Ministry of Transports and Communications. (2015) Regulation of the Law $N^{\circ} 29022$ - Law for the strengthening of the telecommunication infrastructure growth - Supreme Decree No 003-2015-MTC. Available at: http://antenasysalud.pe/wp-content/uploads/2015/04/MTCNuevo.pdf

OSIPTEL. (2015). Indicators of Mobile Service, Lima-Peru. Lima: OSIPTEL. Available at https://www.osiptel.gob.pe/documentos/2-indicadores-del-servicio-movil (in spanish)

Peruvian Congress. Law for the Strengthening of the Telecommunication Infrastructure Growth-Law 29022 (in Spanish). Available at https://www.osiptel.gob.pe/Archivos/Sector_telecomunicaciones/Legislacion_Telecom/LeyN29022-ExpInfraTeleco.pdf

Peruvian Congress. Modification of the Law for the Strengthening of the Telecommunication Infrastructure Growth - Law 30228 (in Spanish). Available at http://transparencia.mtc.gob.pe/idm_docs/normas_legales/1_0_3376.pdf

Royal Society of Canada. (1999). A Review of the Potential Health Risks of Radio Frequency Fields from Wireless Telecommunication Devices. An Expert Panel Report Prepared at the Request of the Royal Society of Canada for Health Canada, RSC/EPR 99-1. Ottawa: RSC.

SCENIHR. (2009). Health Effects of Exposure to EMF. Bruselas: European Commission. Available at http://ec.europa.eu/health/ph_risk/committees/04_scenihr/docs/scenihr_o_022.pdf

WHO. (2006). Electromagnetic Fields and Public Health: Base Stations and Wireless Technologies. Fact Sheet No 304. Geneva: WHO. Available at http://www.who.int/peh-emf/publications/facts/ fs304/en/

WHO. (2007). Proceedings of the International Workshop on Base Stations and Wireless Networks: Exposures and Health Consequences (Geneva, June 15-16, 2005). Milan: WHO.

WHO. (2014). Electromagnetic Fields and Public Health: Mobile Phones. Fact Sheet No 193. Geneva: WHO. Available at http://www.who.int/mediacentre/factsheets/fs193/en/

WHO. (2015). Electromagnetic Fields (EMF) Geneva: WHO. Available at http://www.who.int/ peh-emf/en/

Zmirou, D. et al. (2001). Mobile Telephones, Base Stations and Health. Current State of Knowledge and Recommendations. A Report to the Director General of Health of France. Paris: Direction General of Health. Available at http://www.sante.gouv.fr/IMG/pdf/Rapport_Zmirou_-_2001.pdf 